\title{
Bir Mutlak Öteki Örneği: Leos Carax Sinemasında Mösyö Merde
}

\author{
Onur Keşapl1*
}

\section{$\ddot{O} z e t$}

Özellikle Soğuk Savaş'ın bitimiyle birlikte kültür ve kimlik kavramlarının sosyal bilimler çalışmalarındaki etkileri artmıştır. Bu durum, öteki sözcü̈̆̈̈ ve ötekileştirme eyleminin öne çımasına neden olmuştur. Ortaya konulan görüşlerin büyük bölümünde, benlik inşası için ötekiye duyulan ihtiyaçtan söz edilişi, ötekisiz bir varoluşun mümkün olmayacă̆ı önermesine sebep olmaktadır. Dönemi, öteki icadı olarak niteleyen Baudrillard içinse, sözcük en başından beri yalnızca Batı için geçerlidir. Gelinen noktada ise ötekisini yitirmiş Batının vardığg nokta soyut bir kökten ötekidir. Ne var ki, somutluğunu yitirmiş ötekinin haricinde, kültür, kimlik veyahut herhangi bir eğilimle temellenmeyen ancak öteki olarak kodlananlar da vardır.

Zaman ve coğrafya fark etmeksizin, Mutlak Öteki olarak kavramsallaştırllabilecek bu gruplarda akıl hastaları, bedensel deformasyon taşıyanlar, kilolular gibi, olağan ve sıradan haricinde görünümlere sahip olanlar vardır. Mutlak Ötekiler dünyanın her yerinde görünüm ve eylemlerle farklllaşmaktadırlar. Çirkin bir görünüm ve kötücül eylemlerle somutlaşan Mutlak Öteki tabirinde dışsallık açısından grotesk, zihniyet bağlamında ise, özellikle Bataille'ın tarif ettiği şekliyle, kötülük kavramları öne çımaktadır.

Ötekinin klasik tanımları ve ötekileştirme eylemlerinin örneklerine, sinemada, git gide daha çok yer verilir olmuştur. Ancak aynı durum Mutlak Öteki için geçerli değildir. Sinema tarihinde, daha çok grotesk görünüm ve beraberinde hoşgörü talebi içeren örnekler haricinde Mutlak Ötekiyi içeren filmler daha çok yakın dönemde gerçekleştirilmiştir. Kariyeri boyunca uç karakterlere yer veren Leos Carax'ın iki filminde yer alan Mösyö Merde, grotesk kötülüğ̈̈ ile Mutlak Ötekiye esaslı bir örnek teşkil etmektedir. Tokyo! filminin Merde epizodunda Tokyo'da, Kutsal Motorlar filminde ise Paris'te görünen Mösyö Merde, flanörleşerek Mutlak Ötekiyi güncel ve çă̆daş uygarlık kıstaslarıyla çarpıştırmaktadır.

Anahtar Kelimeler: Leos Carax, Mösyö Merde, Mutlak Öteki, Kötülük, Grotesk, Öteki

*ORCID: 0000-0001-5686-2353

E-mail: onur.kesapli@usak.edu.tr

DOI: $10.31122 /$ Sinefilozofi.676106

Geliş Tarihi - Recieved: 15.01.2020

Kabul Tarihi - Accepted: 30.04.2020 


\title{
An Example for Absolute Other: Monsieur Merde in Leos Carax Cinema
}

\author{
Onur Keşapl1*
}

\begin{abstract}
The impact of culture and identity notions within social science studies increased, especially right after the end of the Cold War. This circumstance caused prominence for the word other and the act of othering. The common ground on this topic reveals that the other is a necessity in order to construct selfness. This leads to the thesis saying that without the other, there is no existence. As for Baudrillard, who describes the era as the invention of the other, the word has been only valid for the West all along. At this point, the conclusion of the West deceiving its other, is an abstract, radical other. However, apart from the other which lost its tangibility, there are groups that are coded as other without basing on culture, identity nor disposition.

In these particular groups, which can be conceptualized regardless of time and region as the Absolute Other, there are people with mental illnesses, with deformed bodies, having weight problems, and in general, whoever has different type of appearance beyond ordinary and common outlooks. In all over the world, the Absolute Others differs with their looks and actions from everyone. In the oneiromancy of the Absolute Other, which becomes concrete with evil actions and ugly complexions, the Notion of grotesque is prominent when it comes to out looks and the Notion evilness is featured as a mindset, especially the way as Bataille describes.
\end{abstract}

Classic definitions for the other and the examples of othering are more often seen in cinema. But it is not valid for the Absolute Other. In the history of cinema, very few films that include examples of the Absolute Other, except from the ones commonly using grotesque appearances in order to demand tolerance, were mostly fulfilled in recent years. Character of Monsieur Merde, appearing in two films directed by Leos Carax, who always showcased extreme characters and figures throughout his career, is an essential example for the Absolute Other with his grotesque evilness. As seen in Tokyo in Merde segment of the film Tokyo!, and in Paris in the film Holy Motors, Monsieur Merde becomes an Absolute Other flaneur as he clashes with contemporary and modern norms of the civilization.

Key Words: Leos Carax, Monsieur Merde, Absolute Other, Evil, Grotesque, Other

*ORCID: 0000-0001-5686-2353

E-mail: onur.kesapli@usak.edu.tr

DOI: 10.31122/Sinefilozofi.676106

Received - Geliş Tarihi: 15.01.2020

Accepted - Kabul Tarihi: 30.04. 2020 


\section{Giriş}

1990'larla birlikte iki kutuplu küresel mücadelenin yerini kapitalizmin galibiyetiyle gelen ve serbest piyasa ekonomisiyle örülü liberal zihniyetin egemenliğine bırakması, benzer şekilde sınıfsal yaklaşımlı ekonomi-politiğinin de ideolojik tartışmalarda ve sosyal bilimlerde merkezi yerini kimlik ve kültür kavramlarıyla inşa edilen öteki söylemine terk etmesine yol açmıştır. Yakın geçmişe dek, başta Batı merkezli anlatıda olmak üzere, yabancı olarak kodlanan tüm birey ve toplumlara yöneltilen öteki sözcüğü ve ötekileştirme eylemi, olumsuz birer niteleme ve eylem olagelmiştir. 1990 sonrasında kavramsallaştırılan öteki sözcüğü ve ötekiye dair söylemle çalışmaların, ırkçılık başta olmak üzere pek çok ötekileştirici edimi aşma yolunda ilerleme amacı taşıdığı ve buna araç olabileceği kabul görmektedir. Ancak aynı söylem ve çalışmaların, ötekileştirmeyi aşmaktan çok farklılıkları kümelendirip farklılaşmayı mutlaklaştırabileceği yönünde eleştirel görüşler de mevcuttur.

Büyük anlatıların ve evrensel söylemlerin geride kaldığı bir dönemde, öteki kavramı ile hareket edilerek ötekileştirme eylemlerinin, ortak insanlık ideali aşamasında, homojen bir armoni sağlayacağını düşünmek elbette gerçekçi değildir. Ancak insanlar arasında farklılıkların, farklılaşmanın öne çıkarılışıyla heterojen bir kitle halini almanın, hoşgörü ediminin sürekliliğine ve hudutlarının genişlemesine bel bağladığ görülmektedir. Öteki kavramının, ötekiliği bertaraf etmek yerine öteki icat etme noktasına taşınması, tüketim toplumu olarak da nitelenen, geç kapitalizmin hükmünde nelere tekabül edebileceği tartışmalıdır ve tartışılmalıdır. Bu tartışma, bir ötekiye ihtiyaç duyulup duyulmadığı, ötekinin niçin var oluğu gibi sorulara da yönelmelidir. Zira bu noktada ortaya konulacak yanıtlar, etik açıdan önem arz etmekte olup insanlığın iletişim ve etkileşim bağlamında nasıl bir gelecek inşa edeceği konusunda belirleyici olabilme imkânına sahiptir. Sanat ve en çok da sinema, söz konusu soruların ve yanıtların işlendiği başat alanlardandır.

Esasen bir teknolojik aygit olarak icat olunan ve takip eden yıllarda bir anlatım aracina dönüşerek sanat başlığı altına yerleşen sinema, doğası gereği sağladığı kitlesel seyirle, diğer sanat disiplinlerinden ayrılmaktadır. Teknolojik bir gelişmenin ürünü olarak, neredeyse başlangıcından beri, çoğaltılabilir oluşu nedeniyle sinema, sanatın biricikliği halesinden de muaf kalabilmiştir. Bununla birlikte, tüm dünyada kitlelerin erişimine hızlıca ve kolayca sunulabilir oluşuyla toplumsal açıdan nüfuzu ve etkisi, diğer sanat dallarına göre daha büyük ölçeklidir. Sinema sanatçılarından bağımsız olarak da yorumlanabilecek bu durum, sinemanın sorumluluğunu arttırmakta, etik bağlamında sinemanın yaptıkları ve yapamadıklarını daha ilgi çekici kılmaktadır. Öteki kavramı ve ötekileştirme eylemine dair sinemanın ortaya koydukları bu açıdan önemlidir çünkü toplumcu bir anlatı hüviyeti kadar sanatın özerkliğinin de sinematografik açıdan karşılanabilir oluşu sinemanın, ötekiye dair önermelerine, etik açıdan sorumluluk yüklediği kadar önermeleri adeta önermesizleştirerek hafifletmektedir. 


\section{Öteki Çağının Kökten ve Mutlak Ötekileri}

\section{Öteki ve Ötekileştirme Üzerine}

Tarih boyunca, farklı coğrafyalar ve zaman dilimlerinde kitleler tarafından, en hafif tabirle dışarıda bırakılmış, topluma dâhil edilmemiş kimselere yakıştırılan öteki sözcüğü, kimi zaman etnik, kimi zaman kültürel, kimi zamansa cinsel eğilimlere yönelik bir ötekileştirmenin, dışlamanın sonucudur. Söz konusu edimler, yine zaman ve mekân açısından farklılıklar göstermekle birlikte fiziksel ya da psikolojik şiddeti de içerecek şekilde meydana gelmiştir. Özellikle azınlıkları bir bütün olarak yorumlarken başvurulan ve Uluç'un (2009: 36) tabiriyle “bizden olmayan, farklı olan, benimsenmiş, kabul görmüşün dışında, çoğu kez 'mazlum' un adı" olarak kullanılan öteki kavramının, mazlum olsun olmasın, teşkil ettiği farklılık neticesinde yabancı kalmayı sürdüren şeklinde bir tanımı da mümkündür. Ilgaz'a göre ötekinin kim ve ne olduğunun başat belirleyeni farklılıktır. Ona göre farklı olan şeyler, düzeni ve denetimi tehdit etmektedir ve beraberinde düzen karşıtlığı barındırmaları da muhtemeldir (Ilgaz, 2001: 13-14). Dolayısıyla farklılık taşıyanlar, ötekiler, olası bir kargaşadan, nüfuz yitimi ve hegemonya değişimden pekâlâ sorumlu tutulabilmektedir.

Görüldüğü üzere aynı anda hem masum hem de suçlu olarak işaret edilebilir haldeki öteki, Terry Eagleton'a (2006: 21) göre bir kült olarak, “ince bir tevazuuyla maskelenmiş küstahça bir kibirle, toplumsal çoğunluğun kendi içinde herhangi bir çatışma ya da çelişki barındırmadığını" ya da "içermediklerini" varsaymaya da yarayabilmektedir. Bu durumda kimin, kimlerin öteki olduğu, olması gerektiği önem kazanmaktadır. Söz konusu hassasiyete rağmen, ötekileştirmeyi aşmak adına o ana dek öteki bellenmişlerle diyalog kaçınılmazdır. Kaldı ki öteki ile temas ve hatta ötekinin kendisi, kimi yaklaşımlara göre vazgeçilmez bir mecburiyettir. Güliz Uluç'a göre ötekinin varoluşu, bireyin psikolojisi açısından önem arz etmektedir:

Öteki sorunsalı birey boyutuna indirildiğinde ötekinin yaratılmasında bireyin psikolojik açıdan sağlığını sürdürebilmesi bakımından bir düşman yaratarak kendinde gördüğ̈ü eksiklikleri ve yetersizlikleri ona (ötekine) yüklemesi, kendisine olan öfkesini ona yönelterek benliğini sürdürmesi durumunun söz konusu olduğu görülmektedir. Burada, bireysel perspektif itibari ile tabir edilen öteki-ötekileştirme sorunsalı, daha büyük düzeylerdeki ilişki ve durumlar için de hem bir çıkış noktası hem de bir açıklama zemini olmaktadır (Uluç, 2009: 45).

Bir kavram olarak ötekinin, aynı zamanda benlik inşası için de bir ihtiyaç olduğuna işaret edilmektedir. Nuri Bilgin de (2007: 179) benzer bir yaklaşımla, "negatif garantimiz" işleviyle yorumladığı ötekiliğin, asgari bir benzerlik gerektirdiğini, zira kendini tanımak ve farklılaşmak için öncelikle kendini onda bulmak zorunluluğu taşıdığını belirtmektedir. Bu durum bir ikiliği de içermektedir ve bu sayede benlik inşasının - ve beraberinde öteki kurgusunun - olmazsa olmazı görülen ayna dizgesinin, ters yüz edilerek kullanımı da olasıdır. Uluḉa (2009: 101) göre ötekilerin aynasına bakarak kendilerini tanımlayan halklar ancak 
böylelikle kendilerini ötekilerden farklılaştırırlar. Öteki üzerine fikir yürütmelerde bu yönde bir izlek, adeta varoluşsal açıdan ötekinin mutlakıyetinin altını çizmektedir.

Ötekinin var olma, benliğe sahip olma kaygılarından doğan güdülenmelerle karşılık bulması, bir başka kavram olarak kaygıya da, tıpkı öteki gibi olumlu bir işlev yüklenip yüklenemeyeceğini sorgulatmaktadır. İnsanlığın, akılcı devrim ve eğilimler ile özerkleşmesi ve beraberinde kendi yaşamına dair sorumluluklar almasının yarattığı kaygıya odaklanan Soren Kierkegaard'a (2012: 155) göre kavram, aynı zamanda bir araca tekabül etmekte ve ilerlemeci bir motif halini almaktadır. Kaygı Kavramı adlı yapıtında düşünür, "doğru bir biçimde kaygılı olmayı öğrenen kişi, nihai noktayı da öğrenmiş demektir." ifadesiyle insanın hayvan ya da meleklerden farkı ve üstünlüğünü kaygıda konumlandırmaktadır. Onun için insan, "bir sentez olduğu için kaygı duymaya muktedirdir, kaygısı derinleştikçe kendisi de yücelir. Bu, genelde düşünüldüğü gibi, dışsal olana ilişkin, kişinin ötesinde değil, kendisinin ürettiği bir kaygıdır" (2012: 155). Bu bakış açısına göre, olumsuz tınısına rağmen tetikleyici ve bununla beraber ilerletici bir hissiyat olan kaygının, bir diğerinden, ötekinden kaynaklı olmasının mecburiyeti bulunmamaktadır.

Benlik inşasının içe dönük, kapalı bir hat içeren aşaması, söz konusu inşanın bir sonuçtan ziyade süreklilik halindeki bir süreç olabileceğini düşündürmektedir. Süreç süresince, bütüncül bir benliğe kavuşup kavuşamamak, ötekiye yönelik ihtiyacın buradan da desteklendiği düşünüldüğünde önem kazanmaktadır. Bakışı Beklerken adlı pasajında, Pınar Köksal Üretmen, varoluştan kaynaklı, özü bütüncül olarak kavrayamama ve dolayısıyla benliğe varabilmek adına her yüzeye - bir bakıma bencilce - çalınan benlik denemelerine, aşk olgusu üzerinden dikkat çekmektedir:

İnsan kendisini hiçbir zaman tam ve bütün olarak göremez. Belki elimizi, bacağımızı, omzumuzu görebiliriz ama kendi gözlerimizle sırtımıza, yüzümüze bakamayız. Kendi gözümüze, bakışımıza bakamayız. Bu nedenle kendimizi eksik ve parçalı tanırız. Kendimizi bir bütün olarak sadece yansımalarda görürüz. Eksik olmadığımızın onayı yansımamızdır. Aynadan ya da ötekinin gözünden yansıyan görüntümüzdür. Bu nedenle ötekinin bakışında kendimizi ararız. Aşk bakıştır. Aşk bizden çıkan, ötekine yönelen ve onun bakışılla bize geri dönen - bütün ve var olma - onayımızdır. Aşk bu döngüsel bakış sayesinde bizi bütünler. Marcel Proust, aradığımız (ya da başka bir bakışla beklediğimiz) şeyin bizden çıkıp karşıdaki yüzeye çarpan ve bize geri dönen şey olduğunu dile getirirken belki de bunu söyler. (Köksal Üretmen, 2019: 63)

Benlik hissini yaşayabilmek adına, ben parçaları çarpıtılan/yansıtılan/çalınan yüzeylerin bir öteki olması, dahası bir birey ya da topluluk ayırt etmeksizin insan olması zorunluluğu olup olmadığı tartışmalıdır. Yeniden Kierkegaard'a dönecek olunursa, özerk bir benlik inşasındaki ısrarındaki umutsuzluğun yol açabileceği tehlikeler daha açık görülebilmektedir;

Ben'in kaybolmasına kadar, körü körüne sonsuzluğa dalan umutsuzluğun yanında kendi ‘ben'inin başkaları tarafından yok edilmesine karşı koyamayan başka bir umutsuzluk vardır. Bu umutsuz, çevresinde kalabalıkları göre göre, birçok insani 
sorunla ilgilene ilgilene başkalarına benzemeyi, sürüye karışmış bir taklitçi, bir numaracı olmayı çok daha kolay ve güvenilir bir yol olarak görür." (akt, Le Gall, 2012: 50).

Söz konusu tespit, ben arayışının ve bu uğurda ötekilerle girilebilecek, yapıcı ya da ötekileştirici, etkileşimin, beraberinde benlik inşasından ziyade, kalabalıklar içinde adeta eriyerek yaşanacak bir benlik yitimine işaret etmektedir. Buradan hareketle, güçlü bir ön kabule sahip benlik inşası kadar, öteki sözcüğünün de kavramsal olarak sorgulanır hale getirilmesi daha doğru olacaktır.

\section{Kökten ve Mutlak Öteki}

Bu doğrultuda, Kötülü̈̆̈̈̈n Şeffaflı̆̆ı kitabında, Batının, özneleşme ve benlik inşası bağlamında, ayna motifi ve yansıtma eylemi esnasında aynılaşır hale geldiğini yazan Jean Baudrillard, dönemi, ötekiyi keşfetme, araştırma ve hatta üretme orjisi olarak betimlemektedir (2012: 118-119). Ötekiyi alımlama ve özümsemeden çok benlik inşası ve özneleşme gayesiyle ötekiye duyulan ihtiyacın belirleyici olduğu Batı toplumunun öteki kurgulama adına farklılık arar hale geldiğini belirten Baudrillard, vaziyeti kökten öteki adlandırmasıyla özetlemektedir. Ona göre ötekiyi farklılıkla ifade etmek kökten yanlıştır ve hatta ötekini öldürenin farklılıktaki bu 1srar olduğu bile iddia edilebilir. Hâlbuki farklılıktan yola çıkarak öğeleri ayırt etme ve sonrasında yeniden bir araya getirmek bir düşten ibarettir (Baudrillard, 2012: 120-121). Bu noktada Baudrillard'ın, öteki kavramı üzerine fikir üreten pek çok düşünürden ayrıldığı konumlandırmaktadır.

Ötekileştirme fiilini temeline yerleştirilen 1 rkçı tutumlar konusunda da Baudrillard'ın görüşü ayrışmaktadır. Ona göre “öteki öteki olduğu, yabancı yabancı kaldığı sürece ırkçılık" yoktur ve "öteki (...) tehlikeli biçimde yakınlaşmaya başladığında rrkçılık ortaya çıkmaya" başlar (Baudrillard, 2012: 122). Bunu destekleyecek şekilde, Slovaj Zizek'e göre gerçek öteki ile kurulan temas, bünyesi gereği kırılgandır ve ötekine yönelik her yaklaşım - yapıcı ve olumlu bir niyet taşıyor olsa da - ötekinin mahremiyet alanına şiddetli bir saldırıya dönüşebilmektedir (2006: 17). Baudrillard'ın kökten öteki olarak tarif ettiği soyutluk, yüzyıllar boyu, özellikle Batı tarafından ve bakış açısından, keşfedilen coğrafyalarda yaşayan halklara uygulanan somut saldırganlıklardan farklı bir konumda yer almaktadır:

Ötekinin kökünü kazımak için girişilmiş olan şeylerin 1şığında, ötekinin yok edilemezliği, yani ötekiliğin sürüp giden kaçınılmazlığı aydınlanıyor. Düşüncenin gücü ve olguların gücü. Kökten ötekilik her şeye direnir: Fethe, ırkçılığa, soykırıma, farklılık virüsüne, yabancılaşmanın psikodramına. Bir yandan, öteki daima çoktan ölüdür, öte yandansa sapasağlam ayaktadır. Büyük oyun budur (Baudrillard, 2012: 137).

Buna rağmen Batının ötekiye duyduğu ihtiyacın onun anlaşılmazlığını, ona yönelik saplantıyı onu yabancılığa, onun yabancılığında zorlamaya yol açtığını belirten Baudrillard için kökten öteki, hem bulunmaz hem de yok edilemez bir şeydir (2012: 138-139). Baudrillard, kendi ötekiliğinin ve farklılığının farkında olmayan ötekinin aynasında, kendi 
kendini baştan çıkarmakta olan Batının, kendi bakış açısı dışında kalan ötekilerin aslında doğal ötekiler olmadığı, baştan çıkarılarak, kendine yabancı kılınarak; icat, hatta yok edilerek meydana getirildiklerini söylemektedir (2012: 147-150). Ona göre ötekinin sırrı, ben olma imkânının benliğe asla aktarılmamış olmasıdır ve ancak dışarıdan gelenin kaçınılmaz saptırmasıyla var olunabilmektedir. Dolayısıyla öteki, kendi irademizle yüz yüze gelinen olmaktan çıkıp, dışarıdan gelenin zorla girişidir ki bunun altında yabancılığın çekiciliği kadar yabancılığın aktarımı da yatmaktadır (Baudrillard, 2012: 155). Öznenin, bu yaklaşıma göre Batının, hakkında çok şey bilinir oluşuyla cazibesini yitirdiğini ve çekici bir cazibeye sahip yegâne olgunun nesne halini aldığını belirten Baudrillard, ötekilik arayışının tek olasılığını da burada konumlandırmakta ve öz yabancılaşma aşımında iki seçeneğe işaret etmektedir:

Yabancılaşmanın ötesine geçmenin iki yolu vardır: Ya - bıktırıcı ve günümüzde pek umut vaat etmeyen - yabancılaşmanın giderilmesi ve kendini yeniden ele geçirme. Ya da diğer kutup; mutlak öteki, mutlak egzotizm. (...) Artık yabancılaşmayla yetinilmiyor; ötekinden daha öteki olana, kökten ötekiliğe gitmek gerekiyor (2012: 163).

Bu bağlamda, Baudrillard'ın soyut olarak bırakmayı sürdürürken kimi nitelemelerle altını çizdiği öteki tartışmasını somutlaştırma babında, uç ve aşkın, mutlak bir ötekiyi taşımanın yerinde olacağını görülmektedir. Baudrillard'ın Batı hudutlarında tuttuğu tartışmanın, söz konusu kültür ve zihniyet yapısında, aynılaşmadan doğan bir açmaza sebebiyet vermiş olması, aynılaşmış yapılanmanın peşine, ideolojik, kültürel ve göstergesel olarak düşmüş olan dünyanın geri kalanı için ne yönde geçerli olduğu muğlaktır. Zira adına pekâlâ dışlama, dışsallaştırma da denilebilecek ötekileştirici etmenlerin, kültürel bir güdülenmeyle hareket etmek gibi bir zorunluluğu olmadığ gibi kültürel bir hedefi de seçmesi şart koşulmamaktadır. Kültür ve kültürün başat unsurlarından olan ulus ve dinin beraberinde, ırk, cinsiyet gibi kapsayıcı başlıklar haricinde kalan ve buna rağmen - veya belki de tam da bu sebeple - dünyanın hemen her yerinde öteki olarak kodlanmayı sürdüren, ya da bir sıfat iliştirilmeden dışlanabilen pek çok toplam bulunmaktadır. Günümüzde, dünyanin hemen her yerinde, engelliler, evsizler, psikolojik hastalar, doğuştan ya da değil - fiziki deformasyonu olanlar, kekemeler, epilepsi ve benzeri gündelik akışı sekteye uğratabilen hastalıkları olanlar, çirkin olarak görülenler, kilo sorunu yaşayanlar eksiklikleri, fazlalıkları ve farklılıklarıyla, resmen ayrımcılığa maruz kalmasalar da olağanlık ve sıradanlık karşısında ötekileşirilmektedirler.

Bir Yahudi'nin, Kürt'ün, Türk'ün, Ermeni'nin, öteki tanımının klasik anlamılla ötekileştirildiği coğrafyalar olduğu gibi öteki olmadıkları ve ötekileştirilmedikleri konumlar da bulunabilmektedir. Almanya'da öteki olan Türk, Türkiye'de öteki değildir. Ermenistan'da öteki olmayan Ermeni ise Türkiye' de öteki olabilmektedir. Bir ulusa tekabül etmeyen, siyah, eşcinsel, yerli gibi gruplar bile, ötekileştirmenin alenen gerçekleştirildiği Kuzey Amerika'nın kimi yerleşimlerinde öteki değillerdir. Fakat önceki paragrafta farklı örneklerle de geliştirilebilecek şekilde sıralanan kümeler dâhilindekilerin, söz konusu kümelerle ilgili bir toplantı benzeri buluşmalar haricinde, dünyanın herhangi bir yerinde, 
öteki olarak kodlanmayacakları bir zemin bulunmamaktadır. Kültür, coğrafya ve zaman kıstaslarını aşan bu durumdaki bir dışlamaya, dışsallamaya ve ötekileştirmeye maruz kalanlara, Mutlak Öteki denilebileceğinden söz etmek mümkündür. Bir kavram olarak Mutlak Öteki, Batı hegemonyası dâhilinde ihraç olunan zihniyet altyapısı beraberinde meydana gelen aynılaşma kapsamında, dünyanın büyük ölçüde tamamına sirayet etmiş bakış açıları ve tekdüze normlar eşliğinde, her koşulda sayıca az olan, dışarıda bırakılan, ötekileştirilen toplamları kapsamaktadır. Tarihi açıdan kültürel temelli olup ırkçılık, farklılık ve yönelimler alt başlıklarında gerekçelendirilen öteki kavramının, aynılaşmayla kaybedilen, yitirildikçe daha da ihtiyaç duyulup talep edilen sürümü, Mutlak Ötekiler tarafından sınırları aşmış bir aşkınlık olarak dünyanın her yerinde karşılanmakta ve uygulanmaktadir.

Bu noktada dış görünüme yönelik farklılığın ve kötü olarak nitelenmenin, her daim olmasa da bir arada anıldığı, ötekileştirici bir önizlemeden söz etmek mümkündür. Richard Kearney'e göre dışsallığa karşı önyargı, çağdaş dünyamızda da hiçbir şekilde ortadan kalkmamıştır ve aşina olmayana "kötü" yaftası yapıştırıp paranoyayı kaşıyan pek çok popüler medya anlatısı ile karşılaşılmaktadır (2012: 87). Bahsi geçen kötü, kötücül eylemde bulunan kişiye yönelik olduğu kadar görünümün estetik kıstaslara göre çirkinliği üzerinden olumsuz bir sıfat olarak da kullanılan bir kötüdür. Bir eylemin kötülüğü kadar bir bedenin kötülüğü de belirli ölçüde öznellik içermekle beraber, aynılaşarak tek tipleşen formlar ve kavramlar havuzunda nesnel şüpheyle yaklaşılması gereken doğrulara dönüşmektedir. Çoğunluk nezdinde, alışılmışın dişında kalan eylem ve görünümlerin deformasyonu, onlara aynı çoğunluk tarafından kötü sıfatının yakıştırılmasına neden olmaktadır. Ancak dışsallığa iliştirilen kötülügüun ötesinde, eylem temelli kötülük bile üzerinde hemfikir olunmuş bir karşılığa sahip değildir. Edebiyat ve Kötülük adlı yapıtında Georges Bataille, kötülüğün benimsenmesine katkıda bulunmayı amaçlamakta, bu doğrultuda Mutlak Öteki ile duygudaşlık kurulabilecek zeminlere yönelik açlımlarda bulunmaktadır. Bataille'a (2016: 12) göre kötülük, taşıdığı egemen değerler sistemiyle beraber bir kavram olarak, ahlak yoksunluğunu öngörmediği gibi, tam aksine "yüksek ahlak"1 şart koşmaktadır. Kötülüğün içselliği ile ilgili girişilen, ötekileştirme karşıtı bu bakış açısı, evrenselleştiği varsayılan pek çok kıstası deforme ederek Mutlak Ötekilerle yüzleşmeyi beraberinde getirmektedir. Kaldı ki, özellikle 1990 sonrasının kimlik ve kültür temelli çalışmalarda, günah çıkarma eşliğinde bir değer olarak önem atfedilen öteki sözcügünün, bir kavram haliyle, olumluluğa içkin oluşuna karşı çıkan görüşler hâlihazırda mevcuttur. Kearney (2012: 24), “tüm 'ben'ler şeytan, tüm 'öteki'ler de melek değildir" derken eleştirel tutumun ben ve ötekiye de eşit ölçüde uygulanmasının doğru olacağını vurgulamaktadır. Bu noktada, iyilik, kötülük ve ahlak sözcüklerini tersyüz eden Bataille için yüksek ahlak, akılcılıkla varılmış bir kademe değildir. Bilakis, bahsettiği ahlak anlayışı için aklın egemenliğinden doğan iyiliğe karşı, ilksel ve çocuksu bir kötülüğü içeren bir başka akıl şarttır;

Aklın egemen olduğu, varlığını sürdürme isteğinin temellendirdiği bu gerçek dünyaya isyan etmenin iki nedeni olabilir. En yaygın olan ve günümüzde sıkça görülen isyanın nedeni, dünyanın akılcı özelliğiyle anlaşmazlığa düşmektir. 
Gerçek dünyanın temel ilkesi akıl değil, geçmişin çocuksu davranışlarından ya da şiddet gösterilerinden doğan keyfilikle bütünleşen akıldır. Bu tür bir isyan İyiliğin, şiddet içeren davranışları ya da nafile çabasıyla tanınan Kötülüğe karşı isyanıdır (Bataille, 2016: 19).

Zihniyet deformasyonunun içselliği yanında, dişsal deformasyon üzerinden şekillenen, iğdiş edilmiş, deformasyona uğramış bedenlerle ilgili kötücül ve beraberinde ötekileştirici anlatılar da mevcuttur. Öyle ki Mutlak Ötekinin ilk belirlenimi, görünüm üzerinden şekillenmektedir. Doğuştan ya da değil, uzuv eksikliği veyahut fazlalığıyla, dışsal deformasyon taşımakta olan figürlerin canavarlaştırıldığı, insanlık dışı addedildiği anlatılar pek çok kültürün mitlerinde, masallarında ve sözel aktarımlarında mevcuttur. Günümüzde fizyolojik engeli veya bedenine yansıyan hastalığı olan pek çok bireyin, önyargı da içerebilmekle beraber, en hafif tabirle bakışlara maruz kaldığı bir gerçektir. Alışılagelmedik olana yönelik bakışların, bakışın taşıyıcılarının zihniyet yapılarından bağımsız olarak, ötekileştirici bir etkiye sahip olabileceğini yadsımak güçtür. Mutlak Ötekiliğin dışa yansıyan unsurlarını kapsama noktasında, başkalaşmış veya başkalık taşıyan bedenleri, figürleri, imajları içeren grotesk sözcüğüne başvurmak yerindedir. Mihail Bahtin kavramı, imgesel imajları üzerinden plastik ve sahne sanatları ile edebiyatta karnaval gibi olağandışı ve uç temsillerde arayarak temellendirmektedir. Ona göre grotesk beden;

Belli bir formu olan, düzenli, tamamlanmış bir beden değildir; kopuk uzuvlar, uzun burunlar, patlak gözler ve girintileri çıkıntılarıyla kendi sınırlarından taşan bir bedendir; bedenin sınır bölgeleri sürekli aktiftir, yeme, içme, dışkılama ve (terleme, sümkürme, hapşırma gibi) bütün diğer madde atımı işlerinin yanı sıra çiftleşme, hamilelik, uzuvların kopması, başka bir beden tarafından yenilip yutulma, bütün bu edimler, bedenin sınır bölgelerinde sergilenir ya da başka bir deyişle eski ve yeni beden arasındaki sınırda. Bu beden dağlarla, nehirlerle, denizlerle, adalarla ve kitalarla kaynaşabilir. Tüm evreni doldurabilir" (Akt. Üzümkesici, 2018).

Arkaik anlatıları çağrıştıran bu tanıma göre grotesklik, zaman dışılık içerdiği ölçüde modern - ve beraberinde akılcılık - öncesi insanlığın geride bıraktığı, günümüz kıstaslarında kabul göremeyecek kimi eylem ve dışavurumları da kapsamaktadır. Rahmi Öğdül'e (2013) göre de grotesk beden, "doğadaki akışlara duyarlı bir bedendir" ve "toplumsal alt üst oluşlarla doğadaki alt üst oluşların örtüşmesi rastlantı" olmadığı gibi "tabakalaşmalara, hayatın akışını kesintiye uğratan kompartmanlaşmalara yönelik hem doğada hem de toplumda grotesk bir tavır" vardır. En çok grotesk ve kötülükle vücuda ve zihne kavuşan Mutlak Öteki, kökten ötekinin yokluktan var edilmesinin aksine somut olarak oradadır ancak çoğunluk tarafından görmezden gelinmektedir. Bu açıdan bakıldığında Mutlak Ötekiyi, kökten ötekinin karşısında konumlandırmak mümkün görünmektedir. Buna karşın işitsel, yazınsal ve görsel anlatılarda, ötekiye dair pek çok sunum ve temsile rağmen, Mutlak Ötekiye dair anlatılar az sayıda ve de çoğunlukla, ötekiliğin toplamı için geçerli olduğu haliyle, basmakalıp tiplemelerden öteye geçmemektedir. Başlangıcından bu yana sağladığı kitlesel seyir ve çoğaltılabilir oluşuyla dünya ölçeğinde süratli erişilebilirliğiyle sinema, bir bütün olarak öteki ve ötekileştirme ile 
ilgili bir görsel hafıza birikimine yol açacak kadar belirleyici olmuştur. Dolayısıyla Mutlak Ötekilere dair anlatılar noktasında da, sinemanın sağladıkları ve sağlayabilecekleri, yedinci sanatın doğası gereği, kitlesel ve erişilebilir oluşuyla, diğer disiplinlere nazaran daha fazla önem arz etmektedir.

\section{Sinemada Mutlak Ötekiler ve Leos Carax Filmlerinde Mösyö Merde}

\section{Sinema Tarihinde Mutlak Öteki Örnekleri}

Bir buluş olarak ortaya çıkışıyla beraber, henüz bir anlatı aracına dönüşmeden önce, bir aygıt olarak sinemanın, belge niteliği taşıyan görüntü parçalarıyla çeşitli kültürlerin eylemlerini kayda alarak Batı nezdinde öteki olarak kodlanan halklara dair sunumlar içerdiği görülmektedir. Yerlilerin dans ve ritüellerini içeren bu görüntülerin devamında, sinemayı bir sanat disiplinine dönüştürecek süreci başlatan, öykü anlatma aracı şeklindeki kullanımı, ilk konulu filmlerin büyük oranda western türüne tekabül etmeleri nedeniyle Kuzey Amerika yerlilerine dair imajların öne çıkmasına sebebiyet vermiştir. Tarih boyunca, yerlilerin Hollywood temelli ana akım kıstaslarında The Searchers (Çöl Aslanı, John Ford, 1956) gibi muhafazakâr ya da Dances With Wolves (Kurtlarla Dans, Kevin Costner, 1990) gibi liberal temsillerle resmedilmeleri, topyekûn bir kültür ve tek tipleştirilmiş bir kimlik olarak düz değişmececi yargılar ve basmakalıp karakterler olarak ötekileştirilmelerine neden olmuştur. Benzer şekilde siyahların, Müslümanların ve ötekileştirilmiş pek çok diğer azınlığın da Hollywood filmlerinde öteki olarak kodlanmaları, dünya sinemasında da başka kültürlerin, inanışların ve ulusların ötekileştirilmesine zemin hazırlamıştır. 1990 sonrası nükseden duyarlılık ve farklılığa yönelik hoşgörü çerçevesinde, anılan azınlıklara ek olarak LGBTI bireylerin de sinemada yer edinişlerinde hatırı sayılır bir artış yaşanırken, Dallas Buyers Club (Sinırsızlar Kulübü, Jean-Marc Vallée, 2013), Moonlight (Ay Işı̆̆ı, Barry Jenkins, 2016) ve benzeri filmlerle örneklendirilebilecek söz konusu temsillerde, ötekileştirmeyi aşma amacı da yaygınlaşmaktadır. Öteki kavramına ve ötekileştirme eylemine dair klasik yorumların ve izahların ekseninde bir izleğe sahip bu arayışlarda, başta konvansiyonel sinema aracılığıyla olmak üzere, imajlar yoluyla sinematografik bir kurguya dönüşmüş ötekilerin, farklı azınlıklar üzerinden ilerleyen örneklerle, söz konusu süreçte, bu kez kültürel ve kimlik hassasiyetleri göz önünde bulundurularak sinemasal tiplemelere dönüştürüldüğü görülmektedir. Gerek konvansiyonel gerekse art house sinema olsun, öteki söz konusu olduğunda rrk, cinsiyet ve cinsel yönelimden ötesine varamayan dünya sinemasinın, ortalamacı politik doğruculuk ekseninde ele aldığı kavramın Mutlak Ötekiye alan sağlamayışı, ötekisizliğinin olanaksızlığının altını çizmektedir. Buna karşın, politik doğruculuğun etkisinin yadsınamayacağı örneklerin yanında, Mutlak Ötekiyi karşılayan filmler de mevcuttur.

Sinemanın klasikleşen canavar/yaratık anlatılarının ötesinde, Mutlak Ötekilere yer veren filmlerin büyük bölümünde, tıpkı öteki kültür ve azınlıklara yapıldığı gibi basmakalıp değer yargilarından hareketle tek tipleştirmenin etkisi görülmektedir. Kilolu ve şişman karakterler güldürü unsuru veya taşlama ihtiyacını giderici rollere büründürülürken, psikolojik rahatsızların cinayet, suç, gerilim ve hatta korku unsurlarıyla bir arada 
verilmesine yönelik örnekler yaygınlık göstermektedir. Akli denge noktasında doğuştan gelen rahatsızlıklar taşıyanların ise, bir filme konu olduklarında özel bir yeteneğe sahip olduğu görülmekte, karakterin öne çıkarılan özelliği bu olmaktadır. Bu anlatıların hemen hepsinde, Mutlak Ötekilere dair keskin bir düşmanlık, canavarlaştırma yok ise, hoşgörü çerçevesinde bir duygudaşlık gayreti göze çarpmaktadır. Ancak özdeşleşme ve Mutlak Ötekilerin oldukları, doğal, sıradan halleriyle bir başkaraktere, anlatı odağına dönüştüğü örnekler az sayıdadır.

Nispeten erken sayllabilecek bir örnek olan Freaks (Tod Browning, 1932), ana karakterlerinin büyük bölümünün Mutlak Öteki olduğu bir film olarak dikkat çekmektedir. Adından da anlaşılacağı üzere, hilkat garibesi grotesk bedenlerle dolu film, serveti uğruna evlendiği cüce kocasını öldürtmeye çalışan bir balerin ile cücenin fizyolojik görünümleriyle mutlak ötekileşen arkadaşlarının duygularını, güdülenmelerini, amaçlarını ve çatışmalarını anlatmaktadır. İyi davranışlar kadar kötü davranışları da kapsayan bir bütünlükte hareket eden aynı anda hem dram hem de korku türünde anılmaktadır. Bunda şüphesiz, yönetmenin, korku filmleriyle anılmasının payı bulunmaktadır. Rekin Teksoy'a (2005: 210211) göre Browning'i dönemin diğer korku türü yönetmenlerinden ayıran özellik, ürkütücü karakterlerine psikolojik temeller de sağlamasıdır ki yazarın sinema tarihinde bir benzeri olmadığını ifade ettiği Freaks, grotesk görünümler ardındaki karakterlerin psikolojilerini yansitma konusunda önemli bir yapittır.

Benzer bir deforme beden vesilesiyle Mutlak Öteki anlatısı olan, Victor Hugo'nun romanı Notre Dame' in Kamburu ise, 1923, 1939, 1956 ve 1996 yıllarında sinemaya uyarlanarak başat bir örnek halini almıştır. Yapıta adını veren kambur ana karakterin, kendisini çevreleyen karakter ve olayların, duygusal gelgitleri eşliğinde devimin kazandığı ve sağl film, Mutlak Ötekiye acıma ve hoşgörü yaklaşımlarıyla aslında pek çok öteki anlatısı eserde olduğu gibi, özdeşleşmeye imkân tanımamaktadır. Mutlak Ötekinin ana karakter olması bu noktada, bakış açısı ve öznelik noktasında bir değişiklik meydana getirmediği gibi yeniliğe de alan açmamıştır. Ancak büyük ölçüde Notre Dame'in Kamburu'ndan esinlenerek kaleme alınan ve filme çekilen, David Lynch'in 1980 yılında yönettiği The Elephant Man (Fil Adam, David Lynch, 1980), hâlihazırda nesne ve beden deformasyonlarıla, dişavurumcu Alman sinemasına öykünerek Eraserhead (David Lynch, 1977) gibi yapımlara imza atan yönetmenin bir diğer grotesk Mutlak Öteki'yi anlattığı bir olarak dikkat çekmektedir. Onulmaz bir deformasyona uğramış yüzü ve başı nedeniyle gösterilerde hilkat garibesi olarak sergilenen bir bireyin, bir doktor vasıtasıyla topluma kazandırılmasının anlatıldı̆̆ı Film Adam'da yönetmen “büyük bir sevecenlikle yaklaştığı kahramanının yüzünü filmin ilk bölümünde seyirciden saklarken, insanların ayrıksı bir görünüş karşısındaki anlayışsızlı̆̆ını büyük bir duyarlılığın ağır bastığı” bir anlatımla vurgulamaktadır (Teksoy, 2005: 825). Canavarca bir görüntünün ardında, sanıldığının ve korkulduğunun aksine kötülük yerine nezaketin ve hatta entelektüel bir zihniyetin yer alabileceğinin altını çizen Fil Adam, Mutlak Öteki işleyişinde hoşgörü ve dışsallığa yönelik önyargı üzerinde durmaktadır. 
Mutlak Öteki kapsamında değerlendirilebilecek sinematografik anlatılarda, dışsallığın yanı sıra dışsal olmayan uçlara dair örnekler de söz konusudur. Hemen her kültürde olumsuzlanan, hatta şeytanileştirilen pedofili konusu, son yıllarda giderek artan sayıda vaka ile daha çok gündeme gelmekte ve kitlesel tepkilere yol açmaktadır. Pedofilinin bir hastalık olup olmadığı tartışması yapılsın yapılmasın, çocuklara taciz başta olmak üzere sözcüğün yarattığı çağrışımların tümüyle kötülüğe işaret edişinin, sinemada da bugüne dek bu yönde kötücül temsillerin ve kötü karakterlerin varlığını doğurduğu görülmektedir. Buna rağmen, dünya üzerinde zaman ve mekân ayırt etmeksizin Mutlak Öteki başlığ1 altında yorumlanabilecek olan pedofiliye odaklanan, duygudaşlık, hatta özdeşleşme amacı taşıyan filmler de mevcuttur. Todd Field'ın yönettiği, Little Children (Tutku Oyunları, Todd Field, 2006), pedofiliyi bir sorun olarak olay örgüsünün çerçevesi haline getirirken aynı zamanda bu soruna sebep olan pedofili bir yan karakteri de anlatmaktadır. Lars von Trier'in, iki bölüm olarak yönettiği Nymphomaniac'ın Vol. 2'sinde (İtiraf: Bölüm 2, Lars von Trier, 2013) pedofili bir karakter ile empatinin kotarıldığı kapsamlı bir sahne mevcuttur. Joren Molter'in yönettiği kısa metraj Kind'de (Joren Molter, 2018) ise pedofili bir karakter, filmin başrolü olarak tüm olay örgüsünün odağını oluşturmaktadır. Little Children'da pedofili karakterin, sözcük üzerine süregelen ürkütücü ve şeytani tasvirleri karşılayacak şekilde tekinsiz, kötü ve çirkin bir görünümü vardır. Toplum tarafından, pedofili etiketi olmaksızın da rahatlıkla ötekileştirilebilecek bir dışsallığa sahip karakterin, pedofiliye dair biriktirilmiş basmakalıp yargıların taşıyıcısı olduğu görülmekte, bu tektipleştirme durumu karakterle empatiye zıt katmanlar kazandırmaktadır. Cinsellik üzerine çeşitli eğilimlerin, yer yer grotesk ve pornografik sunumlarla yer edinirken felsefi ve daha çok ahlaki tartışmalarla ele alındığı Nymphomaniac' da, pedofili bir karakter içeren kısa ancak etkin bir sahne mevcuttur. Burada, Little Children'ın tam tersi bir tercih ile pedofilin toplumun dışsal kıstaslarına uyan, hatta olağan bir bireyinin, beyefendi görünümü altında yatan giz dışa vurulmaktadır. Ve bu açığa çıkarılış anında meydana gelen duygu durumu üzerinden bir bağ kurdurma niyeti göze çarpmaktadır. Kind filmindeyse, bir müze gezisinde kendi kız çoğuyla beraber, kızının sınıfından bir diğer çocuğa göz kulak olmakla görevli, olağan ve duyarlı görünen bir kadının, kendisini bir anda içinde bulduğu gelgitler neticesinde yaşadığı gerilimin yansımaları anlatılmaktadır. Pedofili karakterin, diğer iki filme nazaran çok daha örtülü bir seyirle işlendiği bu filmde aynı zamanda başrol oluşu, kendi içinde yaşadığı duygusal çatışmaların izleyiciye dolaylı olmadan aktarılmasını sağlamaktadır.

Kısa metraj filmlerin daha çok sayıda üretilir hale geldiği ve uzun metrajlara nazaran nispeten daha özerk oluşlarından ötürü daha az örnekle karşılaşılan konulara eğildiği görülmektedir. Kind gibi daha katmanlı bir Mutlak Öteki sunumuna yer veren, The Things You Think I'm Thinking (Sherren Lee, 2017), eşcinsel ilişkilerin tabu hatta öteki olmaktan yavaş yavaş çıktığı günümüzde, ötekileştirme tartışmasını adeta bir sonraki aşamaya taşımaktadır. Film, bir yangından sağ çıkmayı başarmış ancak yüzü ve bedeninin deformasyonun yanı sıra, kimi uzuvlarını da yitirmiş bir gencin yeniden ilişki kurma çabalarına değinmektedir. Grotesk görünümü nedeniyle maruz kaldığı bakışlar esnasında sağlamayı başardığı bir ilişki esnasında ise zihninden geçen ve dile getirdikleri, filmin Mutlak Ötekiler bağlamında sinemada bugüne dek söylenegelen ezberlere yönelik tepkiler 
şeklinde yorumlanmaya açıtır. Ana karakter kendisiyle birlikte olmak isteyen kişiden şüphelenirken, bir çeşit acıma, hoşgörü unsuru olup olmadığında veyahut bir nevi örtülü fetiş objesi şeklinde görülüp görülmediğinden emin olmak istemektedir. Bu muğlaklık, Mutlak Öteki olmanın, bugüne dek sinemada sunulan seyriyle sinırlı tutulamayacak bir ötekileştirme ile karşı karşı kalmaya eşdeğer olduğunu göstermektedir.

Ana akım sinemanın dışında kalan filmlerde değerlendirilmeye devam edilen Mutlak Ötekinin, Ali Abbasi'nin yönettiği Gräns (Sınır, Ali Abbasi, 2018) filmiyle kapsamlı bir şekilde işlenmeye çalışıldığı görülmektedir. Alışılmadık bir yetiyle, insanların korku, endişe, suçluluk gibi hislerini koklayabilen gümrük memuru Tina' nın hikâyesinin anlatıldı̆̆ı film, ana karakterin mesleğindeki başarısı neticesinde büyük bir pedofili şebekesini açığa çıkarmasıyla paralel olarak sıra dışı bir iletişime girdiği Vore ile artan etkileşime odaklanmaktadır. Tina ve Vore'nin doğa ile bütünleşik halleri ve özellikle yüzlerindeki deformasyonla altı çizilen grotesk bedenleriyle Mutlak Öteki temsiline dönüşen Sınır, organize pedofil suç örgütünün lideri olarak Vore'yi konumlandırmasıyla, karakteri Mutlak Ötekiden mutlak kötüye dönüştürmektedir. Kötülük ve grotestkliğin Mutlak Ötekide bütünleşik tasvirini karşılayan film, Tina ve Vore'nin aslında birer insan değil, İskandinav mitolojisinden trol olduklarını açık etmesiyle ötekileştirmesini adeta sınır ötesine taşımaktadır. Doğurgan bir trol olarak her ay döllenmemiş trol yumurtaları dünyaya getiren ve insan bebeklere benzerliklerini kullanarak yeni bebek sahibi olmuş insanların çocuklarıyla onları değiştirirken çaldığı bebekleri pedofil suçunu da içeren insan tacirlerine veren Vore'nin karşısında ise tüm insanlığın kötü olduğuna inanmayan Tina konumlanmaktadır. Mutlak Ötekilikten sınırın ötesine taşınarak insan dışı konumu pekiştirilen, ancak insanlar tarafından yetiştirilmesi sonucunda Vore'ye göre daha insan ve en önemlisi daha iyi olmayı başarmış Tina'nın, Vore'yi durdurma çabası, genel ve nesnel iyilik çıtasına işaret etmektedir. Nietzsche'nin ortak iyiliğine ne denli göreceli olduğuna dem vuran görüşleriyle (2019: 50) birlikte değerlendirildiğinde filmin iyi kötü çatışmasını klişeleşmektedir. Abbasi ve filmin başrol oyuncularının gerçekleştirdiği bir söyleşide (2018), Sınır'ın tam da son yıllarda artan öteki ile duygudaşlık, alımlama, özümseme niyetli filmlerde kodlanan güzellik anlayışına karşı Mutlak Ötekileri de kapsayacak bir uzama varmasının hedeflendiği ifade edilmektedir. Ancak film, özellikle Mutlak Ötekilik üzerinden taşıyabileceği özgün önemi reddedişiyle kaçırılmış bir fırsat izlenimi uyandırmaktadır. Bu noktada, Thomas Mann'ın burjuva karşıtlığı olarak betimlediği groteskliği, içeriksel duygudaşlık adına bir eğretileme şeklinde kullanmayı tercih eden Abbasi, Flannery $\mathrm{O}^{\prime}$ Connor'ın groteskliğin gücünün, bu doğrultuda tercih edilmesini eleştirdiği pasajı akla getirmektedir. Ona göre şimdilerde sanatçlar için adeta bir zorunluluk olarak görülen duygudaşlık, zaafların her türlüsünün hoş görülebildiği ve dolayısıyla sanatçıların artık herhangi bir şeye karşı konumlanmasının mümkün olmadığı bir düzlem yaratmaktadır. Hâlbuki O'Connor'a göre grotesk kavramı doğru kullanıldığında, içerdiği zihinsel ve ahlaki yargıların duygulara baskın geleceği aşikârdır (2019). Tüm bunlarla beraber, Abbasi'nin, Sınır ile ortaya koyduğu Mutlak Öteki tartışmaları önem arz etmekte ve yönetmenin sonraki yapitlarında konuyu ve kavramı nereye taşıyacağına dair merak uyandırmaktadır. 
Mutlak Ötekiye dair yapıtların azlığında, bir bakıma bakış açısının öteki sözcüğünün klasik anlamlarına odaklanmasından da kaynaklandığı söylenebilir. Hâlbuki uçlarda karakterleri işleyen, işlerken öteki veya ötekileştirme odağı taşımayan yönetmenler de bulunmaktadır. Fransız sanatçı Leos Carax söz konusu yönetmenler arasında yer almaktadir.

\section{Leos Carax Filmlerinde Bir Mutlak Öteki Örneği Olarak Mösyö Merde}

1960 doğumlu Carax, 1980' de başladığı yönetmenliği süresince beş uzun metraj, bir orta metraj ve sekiz kısa metraj film çekmiştir. Fransız sinemasının ulusal kodlarından şiirsel gerçekçiliği karşılayacak şekilde metaforlarla örülü içeriklerini, ülke sineması kadar dünya sinemasının da biçiminde radikal değişiklere yol açan Fransız Yeni Dalga akımının sıçramalı kurgusu ve bilinçli bir deformasyona uğratılmış sinematografiyle birleştiren Carax, auteur nitelemesini karşılamaktadır. İlk uzun metrajı Boy Meets Girl (Leos Carax, 1984) ile onu takiben çektiği Mauvais Sang (Kötü Kan, Leos Carax, 1986) ve Les Amants du Pont-Neuf'de (Köprü Üstü Âşıkları, Leos Carax, 1991) aynı oyuncular aynı karakterleri yöneten Carax, gerçeküstü öğelerle psikolojik durumları tasvir eden bir sinema anlayışını uygulamaktadır. Yönetmenin odağında yer alan anlatıların, evsiz, bohem, psikolojik ve fiziksel olarak hırpalanmış, sakatlanmış, hastalanmış karakterlerle işlenmesi, Carax'ın Mutlak Öteki kavramı üzerinden okunabilir bir sanatçı olduğunu göstermektedir.

Toplum dışı karakterlerin tetiklediği filmografisindeki beş uzun metrajıyla, içerik biçim açısından yapıbozumcu olarak tanımlanabilecek bir sinema ortaya koyan Leos Carax'ın son iki filminde yer alan ve tıpkı ilk üç uzun metrajında olduğu gibi oyuncu Denis Lavant tarafından canlandırılan Mösyö Merde, eylemleri ve görünümüyle Mutlak Ötekiye kavramı için başat bir örnek teşkil etmektedir. Tokyo!'da (Leos Carax, Michel Gondry, Bong Joon Ho, 2008) Japonya' da, Holy Motors'da (Kutsal Motorlar, Leos Caras, 2012) ise Fransa' da görülen karakterin herhangi bir kültürel uzama ya da kimliğe sahip olmayışı, modern kıstaslar nezdinde hilkat garibesini andıran görünüşü, onu çoğunluk açısından korkutucu bir figüre dönüştürmektedir. Yeraltından gelişi, deforme imajı, renkleri ve kötücül saldırganlığıyla Tokyo açısından Gojira (Godzilla, Ishiro Honda, 1954) alegorisi halini alan Merde'nin, Paris'te de benzer dışavurumlarda bulunması, onu grotesk bir flanöre, ve alegorinin alegorisine dönüştürmektedir.

İlk olarak 2008 yılında, Bong Joon Ho, Michel Gondry ve Leos Carax'in birer orta metrajıyla epizodik bir uzun metraj halini alan Tokyo!'da, Carax'ın yönettiği Merde adlı pasajda yer alan Mösyö Merde, Fransızcada bir küfre karş1lık gelen sözcügüün vücut bulmuş ve dişa vurulmuş halidir. Tokyo'nun işlek bir caddesinde, kanalizasyondan çıkan Mösyö Merde, hızlı adımlarla yürüyerek yolda karşısına çıkan insanları canavarımsı görüşünü ve saldırgan davranışlarıyla korkutmaktadır. İnsanların sigaralarını çalan, paralarını ve çiçeklerini yiyen, engellilere saldıran, genç kızların koltuk altını yalayan, çarptığı kişileri deviren, sigara izmaritini bir bebeğin üstüne atan Merde, anlam verilemeyen davranışlarının ardından yer altına geri döner. Buradaki gezintilerinde, 2. Dünya Savaşı'nda Japon İmparatorluğu'nun hırpalanmış sancağıyla beraber pek çok mühimmat 
bulan Merde'nin bir sonraki hedefi, şehir trafiğinin ve beraberinde kalabalıkların olduğu, Tokyo' daki bir diğer merkezi noktadır. Orada rastgele el bombalarıyla adeta terör estiren Merde, Japon televizyonların da ana gündem maddesidir. Güvenlik güçlerince, kanalizasyonlarda yakalanan Merde, idam edilmek üzere yargilanırken, kendisiyle aynı grotesk görünüme sahip bir Fransız avukat tarafından savunulur. Japon kamuoyunu ve halkını ikiye bölen Merde, bir yanda karşılaştıkları tüm Beyazlara saldıran, idam taraftarı bir kesime yol açarken diğer taraftan idam karşıtı olmanın yanında Merde'nin görünümü ve davranışlarını taklit eden ve hatta oyuncaklarını üreten bir kesim meydana getirir. Mahkemede Japon yetkililerle tartışan Merde' nin eylemlerine yönelik bir pişmanlığı yoktur ve idam kararı onanır. İdam esnasında ise öldü sanılan Merde'nin bir anda kayıplara karışmasıyla film sonlanır.

Mösyö Merde'nin ötekiliğini mutlaklaştıran, herhangi bir duygudaşlık üzerinden geliştirilebilecek bir acıma, hoşgörü tepkimesine imkân tanımayan kötülüğünün yanında, görünüşünün norm dışılığıdır. Bakımsız ve pis bir görünüm, ilk bakışta evsizleri andırmaktadır ancak Merde'nin saçı, sakalı, el ve ayaklarının grotesk ürkütücülüğü davranışlarıyla birleştiğinde toplum için şeytani bir hal almaktadır. Merde'nin yeraltından çıkışı, yeşil bir kıyafet giyer oluşu, çirkin ve iri ayaklarıyla büyük adımlar atarak ilerlemesi ile göründüğü ilk sahne boyunca çalan müzik, Leos Carax tarafından Mösyö Merde'yi, Japon yönetmen Ishiro Honda'nın 1954 yılında yönettiği, sonrasında popüler kültüre Godzilla olarak geçen, Gojira adlı filmde, filme adını veren canavarla eşleştirir olduğunu kanıtlamaktadır. Yeraltından ansızın gelen ve modern Tokyo'daki işleyişi büyük ve anlamlandırılamayan bir yıkıcılıkla bozan, sürüngenimsi yeşil canavarın görünümü ve ayrıntıları, çalan tema müziğinin de aynı olması bir rastlantıdan fazlasını içermektedir. Gojira, ABD’nin 2. Dünya Savaşı'nda Japonya'nın Hiroşima ve Nagazaki kentlerine attığı atom bombasının bir alegorisidir. Film boyunca bilimciler, bilinen zaman öncesinden kalma bu canavarın yeniden yeryüzüne gelmesinde nükleer çalışmaların önünü açtığı atom bombası denemelerinin ve uygulamalarının neden olduğunu dile getirirler. Gojira atom bombaları nedeniyle yer altında uyanmış, nükleer çalışmaların atıkları nedeniyle yenilmez olmuş ve geri geldiği yeryüzünde karşısına çıkan her şeyi yok eder hale gelmiştir. Film, hiçbir mühimmatla durdurulamayan Gojira'nın, kontrolden çıkmış bir başka deney silah sayesinde alt edilmesiyle sonlanırken, karakterler vasıtasıyla yönetmen nükleer çalışmalar ve atom bombası karşıtı söylem ve önermelerin altını çizmiştir.

Merde'nin Gojira halini alışı, mekân, eylem, görünüm ve müzik benzeşiminden fazlasına tekabül etmektedir. Atom bombasının alegorisi olan Gojira üzerinden Leos Carax'ın kötülük ve hoşgörüyü sınarken 2. Dünya Savaşı'na dair başka bir tarih yazımına da işaret ettiği söylenebilir. Zira Merde'nin saldırılarında edindiği silahların, Mihver Devletler arasında yer alan ve Asya kıtasını işgal eden Japon İmparatorluk unsurlarından edinmesi ve yakalandıktan sonra talep edip yediği tek şeyin İmparatorluk ailesi için kutsal sayılan çiçekler oluşu dikkat çekmektedir. Savaşta Japonya'nın yenilgiyi kabul edip teslim olmasında, ABD'nin atom bombası gücünü görmüş olmalarının belirleyici olduğuna dair anlatı son yıllarda aksi yönde söylem ve içeriklerle karşılanmaktadır. Oliver Stone' un 2012- 
2013 yıllarında yönettiği The Untold History of the United States belgesel dizisinin üçüncü bölümü olan The Bomb'da (Oliver Stone, 2012) da yer alan belgeler, Japonya'nın ve İmparatorun, atom bombaları sonrası teslim olmayı düşünmedikleri, ancak ne zaman ki Sovyetler Birliği'ne bağlı Kızıl Ordu'nun Japonya işgali gündeme geldiğinde, İmparatorluğun ABD'ye teslim olmaya karar verdiğini göstermektedir. Japon İmparatorunun, 1917 Devrimi esnasında kendi çarlarını idam eden komünistlere teslim olmaktansa ABD'ye teslim olmanın rejimi koruyacağı öngörüsü doğru çıkmış, Japonya ABD etkisinde savaş sonrası yeniden inşa olunurken İmparatorluk yerinde kalmıştır. Bu verilerle Tokyo!'da Merde vesilesiyle, alegorinin alegorisini ortaya koyan Carax'in, kendisine atom bombası atmış düşmanı bile affedebilen ve dostluk kurabilen, hoşgörü ve saygı tutumları örnek teşkil edecek şekilde gelişkin Japonya idealini iğdiş etmektedir. Kaldı ki Merde'nin kötü eylemleri karşısında hoşgörünün sınanması da bunun altını çizmektedir.

Dolaylı bir sunum içermeyen Gojira benzetmesinin haricinde, özellikle kıyafeti ve bedensel açıdan kapladığı alan ile Kelt mitolojisinde kötücül cinler olan Leprikonlara ve Fatih Yürür'e göre de İskandivan mitolojisinin trollerini çağrıştıran Merde, kimsenin anlamadığı bir lisanda konuşurmuşçasına sesler çıkartırken, toplumun ve de mevcut eğilimlerin güzel olarak lanse ettiklerine yıkım getirirken, doğal güzellik temsili olarak çiçekleri ve sistemin suni güzelliğe araç olarak sunduğu paraları yiyerek beslenmektedir (Yürür, 2016: 108). Yüzeysel bir değerlendirmeyle, pekâlâ kapitalizm karşıtı olarak para yiyen, nüfus artışına karşıt olma noktasında engelli bireylere ve yeni doğanlara tepki gösteren, çiçek yer oluşuyla vegan şeklinde etiketlenebilecek Merde'nin kim olduğunun ve nereden geldiğinin anlaşılamaz oluşu onu Mutlak Öteki yapmaktadır. Japon haberlerinde hakkındaki ihbarlarda ve yakalandıktan sonra kim olduğuna yönelik iddialarda, Merde'yi bir çocuk pornosunda görmüş olduğunu ifade eden bir kişinin oluşu, karakterin kötülükle bağdaştırma noktasında dikkat çeken bir ayrıntıdır. Mutlak Ötekiliğin grotesk görünümü ve kötücül eylemlerinin yanı sıra zihniyet açısından da olabilecek en affedilmez günahlar Merde ile yan yana getirilmeye çalışılmaktadır.

Sorgu ve mahkeme sahnelerinde ise Merde, aynı dili konuştuğu tek kişi olmasının ötesinde, görsel ve işitsel benzeşimleriyle kendisi gibi bir Mutlak Öteki halindeki Fransız avukat aracığıyla eylemlerini savunur. Japon yetkililer açısından ve modern dünyanın evrensel insan hakları açısından da savunulur bir yanı olmayan söz konusu saldırganlıklarını neden yaptığına dair sorulara karşılık Merde, masum ve iyi insanlardan nefret ettiğini dile getirir. Bataille' ın (2016: 19) kötülük izahında yer alan "insanlıktan ve iyi davranışlardan nefret eder; çünkü her ikisi de onda şeytanca duygular yaratmaktadır" cümlelerinin adeta öznesi olan Merde, neden Japonlardan nefret edip onlara saldırdığ 1 yönündeki soruyu ise Japonların çok çirkin bulmasıyla açıklar. Yetkililerin Merde'ye kendisini güzel bulup bulmadığıyla ilgili sorusuna ise yanıt olarak Merde, aynaya bakmasının tanrısı tarafından yasaklandığını ancak annesinin ona çok güzel olduğunu söylediğini belirterek yanıt verir. Bu yanıtla, ayna ile bir temas yaşamamış Merde'nin, en asgari şekliyle bir ben fikrine ve benlik inşasına sahip olmadığı söylenebilmektedir. Devamında Merde, Japonların gözlerinin kadın cinsel organına benzer oluşu ve en çok da 
uzun ömürlü olmaları nedeniyle onlardan nefret ettiğini ekler. Bu noktada Merde'nin eylemleri ve gerekçelendirme biçimleri, Bataille'ın kötülük tanımlarıyla uyumlanmaktadır. Ona göre insanlığın iki amacı vardır: "Biri olumsuzdur ve hayatı muhafaza etmeye (ölümü engellemeye) dayanır; olumlu olan diğer amaç ise hayatın yoğunluğunu artırmayı temel alır" (Bataille, 2016: 62-53). Merde'nin söylemleriyle daha da derinleştirdiği uyuşmazlık, Baudrillard'ın (2012: 153) Mutlak Öteki değinisini birebir karşılamaktadır. Kökten insanlık dışı haliyle, hakkında hiçbir şey bilinmeyen ve görünüş itibarıyla esasında insandan farklı bile gözükmeyen ancak her şeyi başkalaştırması ve kendisiyle ne bir pazarlık ne de uzlaşma olanağı tanımayan biçimiyle Mösyö Merde Mutlak Ötekiliğin vücut bulmuş halidir.

Mösyö Merde'nin ikinci kez sahne alışının gerçekleştiği, 2012 yapımı Kutsal Motorlar'da, Leos Carax, dokuz kısa metrajdan oluşan bir film şeklinde de değerlendirilebilecek bir anlatıyla, adı konulmamış bölümlerden oluşan bir yapıt ortaya koymuştur. Paris'te bir limuzinde kendisine verilen çeşitli işlere doğru yol alan, Denis Lavant'ın oynadığı Bay Oscar, gün boyunca karakterden karaktere bürünerek, filmde telaffuz edilmemesine rağmen apaçık şekilde oyunculuk yapmaktadır. Filmin adında yer alan "motor" sözcüğü üzerinden ve de Carax' in kendisinin yer aldığı, siyah beyaz bir filmin oynadığı sinema salonunda şekillenen açılış sahnesi göz önüne alındığında, sinema tarihine dair bir görsel söz içerdiği söylenebilecek film, bir bütün olarak gerçeklik ile sinema arasında bulanıklaşmış sınırlarda seyretmektedir. İmaj üretiminin ve imaj üreticilerinin, teknolojinin ilerlemesi ve erişilebilir olmasıyla da arttı̆̆ı günümüzde, insanlığın gerçek ve hakikat ile olan etkileşimine dikkat çeken Kutsal Motorlar, sinemanın tekelinden çıkmış kameraların adeta görünmezliğe varacak denli küçülüp çoğalmalarını anlatı çerçevesi olarak belirlemiştir. Johannes Pause' a göre filmin çizdiği hudutlarda, herkesin birer rol oynar hale geldiği gündelik hayatta eşanlı olarak yine herkesin kendi gerçekliğinin birer izleyicisi haline geldiği görülmektedir (2014: 133). Yaşamın gerçekliği ile görüntülerin gerçekliğinin iç içe geçerken birbirlerinin yerine de geçer oldukları bu aşkın gerçeklikte, aynı anda hem nesne hem özne olunabilmesi ortada ne nesne ne de öznenin kalmadığını göstermenin yanı sıra klasik anlamda bir ötekine de alan tanımamaktadır.

Filmde Bay Oscar'ın işlerinden biri olan Mösyö Merde rolünün, Bay Oscar tarafından da sevilmediği görülür. Buna rağmen makyajını yapan ve kostümünü giyen Bay Oscar, Mösyö Merde'ye dönüşerek limuzinden kanalizasyonlara geçiş yapar. Tokyo'nun aksine Paris kanalizasyonlarında Merde yalnız değildir. Mültecilerin ve evsizlerin hareket halinde oldukları ve konakladıkları kanalizasyonda hiçbir bakışa veya ilgiye maruz kalmayan Merde, dünyada belki de ötekinin olmadığı sayılı mekânlar arasında yer alan, Paris'in ünlü Pere Lachaise Mezarlığı'nda yüzeye çıkar. Tokyo'daki gibi, görünümü ve eylemleriyle insanları ürküten Merde, çiçek ve para yemeye, engelli insanlara saldırmaya ve sigara içmeye devam eder. Mezarlık sınırlarında gerçekleşmekte olan bir moda çekimine gözü takılan Merde, neler olup bittiğini anlamaya çalışır ve Eva Mendes'in canlandırdığı model ile ilgilendiği görülür. Etraftaki insanların ve çekimde çalışanların ürkmüş hallerine karşılık model herhangi bir tepki vermez. Dahası, çekimleri gerçekleştirmekte olan ünlü fotoğrafçı Merde'nin görünümü karşısında büyülenir. Çok güzel bulduğu Merde ile bir 
çekim yapma isteğiyle çalışanını ona doğru yönlendirir ve model ile beraber bir güzel ve çirkin temsili sunmalarını teklif eder.

Bu noktada grotesk bir bedenin, değişen ve başkalaşan estetik kıstaslar nezdinde güzel bulunabildiği bir vaziyet vuku bulmaktadır. Baudrillard, Batı toplumunda gelinen bu noktayı "biçimlerin, çizgilerin, renklerin ve estetik kavramların özgürleşmesiyle, tüm kültürlerin ve üslupların kaynaşmasıyla toplumumu genel bir estetikleşmeye, karşı-kültür biçimleri dâhil olmak üzere tüm kültür biçimlerinin terfi etmesine, tüm temsil ve karş1temsil modellerinin göklere çıkarılmasına" (2012: 20-21) yol açtığ1 şeklinde değerlendirmektedir. Ona göre güzel ya da çirkin gibi değer yargılarının olanaksızlaşması, beraberinde umursamazlığa mahkûm olmaya ve estetik zevkin yerini büyülenmeye bırakmasına neden olmaktadır. Baudrillard, trans-estetik olarak adlandırdığı bu durumda, güzel ve çirkinin karşılıklı çelişkilerinden kurtulmalarıyla beraber aslında çoğaldıklarını, böylelikle güzelden daha güzeller gibi çirkinden daha çirkinlerin ortaya çıktığını belirtmektedir (2012: 22-23). Mösyö Merde'nin kendisine yapılan teklife verdiği yanıt ise çalışana saldırıp, ısırdığı parmağını koparmak, modelin yanına gidip kanlı ağzı ile koltuk altını yalamak ve kalabalığın korku dolu bakışları ancak fotoğrafçının ilgi ve beğeni dolu fotoğraf çekimleri eşliğinde modeli kaçırıp yer altına götürmek şeklinde olur. Tümüyle sessiz model ile ne olduğu anlaşılmayan sesler çıkaran Merde'nin iletişimi daha çok vücut diliyle şekillenir. Sonrasında Merde vücudunun büyük bölümü açıta olan modelini giysilerini burka ve çarşafı andıran bir hale getirir ve yalnızca gözleri açıkta kalacak şekilde modelin üzerine geçirir. Kendisi ise soyunan Merde, bir çeşit duayı andıran ancak anlaşılamayan hareketlerinin ardından deforme bedeni ile modelin dizine çırılçıplak yatıp uykuya dalar. Kutsal Motorlar' in Merde bölümü, modelin uykudaki Mösyö Merde' yi bırakıp yeraltından çıkmasıyla sonlanır.

Mösyö Merde'nin kanalizasyonu paylaştığı ötekiler tarafından, tüm canavar görünümüne rağmen herhangi bir şaşkınlık yaratmaması, Mutlak Ötekinin, Batıda, Batının ötekileriyle karşılaşması şeklinde yorumlanabilir. Mülteci akınlarından doğan krizlerle haşır neşir Batıda, hayatta kalmaya çalışan göçmenler ve evsizler için Mösyö Merde bir tehdit unsuru değildir. Ayrıca Merde'nin mezarlıkta etkileşime girdiği Batı toplumu açısından Tokyo benzeri bir şekilde tepkimeye yol açmasına rağmen, fotoğrafçı nezdinde güzel bulunur olması Merde için bir yeniliğe tekabül etmektedir. Filmde mezarlık taşlarında internet adreslerinin yazılışılla, Merde'nin bir reklam setinde saldırganlaşmasıyla, Leos Carax'ın Batı toplumunun resmini çekmeye giriştiği söylenebilir. Batının öteki ihtiyacı ve ötekileştirici tutumu sonrası dışlanan kesimlerin de filmde yer alışı, bir Mutlak Öteki olarak Mösyö Merde'nin Kutsal Motorlar'da öteki kavramına farklı ve eleştirel bir bakış açısı sağladığını düşündürtmektedir. Ayrıca Merde'nin modelini çarşaflı hale getirişi, Fransa ve Batıda Müslümanlığa yönelik tepkili ve kaygılı bakış açısının ötekileştiriciliğini akla getirmektedir. Yalnızca gözleri açıkta kalan, burkalı modelin dizlerine yatmadan önce Müslümanları çağrıştıracak şekilde ellerini açıp ardından yüzüne götüren Merde'nin bir Mutlak Öteki olarak öteki kurgular hale geldiğini göstermektedir. Jeremy Biles (2013: 4) bu sahneyi, Hristiyanlığın peygamberi İsa' nın annesi Meryem ile birlikte, sıklıkla resmedilmiş 
anlatısı pieta'ya benzetmektedir ki bu durumda Mutlak Öteki, bizzat şekil verdiği öteki ile ötekileştirici zihniyetin görseli halini almaktadır.

Tokyo! ve Kutsal Motorlar'da, Leos Carax'ın yarattığı Mösyö Merde karakteri ve yaptıkları, Zizek'in ötekiyle girilen etkileşimde şekillenen hissiyata yönelik açıklamasıyla örtüşmekedir. Ona göre "ötekine her zaman aşırı bir keyif atfederiz: (bizim hayat tarzımızı mahvederek) keyfimizi çalmak istiyordur ve/veya gizli, sapıkça bir keyfe ulaşabiliyordur. Kısacası, aslında 'öteki'nde canımızı sıkan şey, tam da keyfini organize etme tarzıdır, tam da bu tarza özgü fazladır, 'aşırılık'tır" (Zizek, 2006: 214-215). Beden ve eylem olarak uç bir seyir sağlayan Merde' nin, çağdaş insanlığın en büyük metropollerinden ikisinde aniden ortaya çıkışı ve Tokyo!'da idam anında kaybolmasının ardından ekranda beliren "Merde $\mathrm{ABD}^{\prime} \mathrm{de}^{\prime \prime}$ yazısından hareketle bir sonraki durağının tıpkı Godzilla hüviyetine bürünerek bu kez ABD'ye saldıran Gojira gibi ABD olacağını öngörmek mümkündür. Bu da bir Mutlak Öteki olarak Merde'yi grotesk bir flanöre çevirmektedir zira Baudrillard'a göre de ötekilerde aradığımız şey yersiz-yurtsuzlaşmadır (2012: 141). Modernite ile beraber gelen sistematik akılcılığın faydacı tekdüzeliğine aykırı bir tipleme olarak avare, başıboş bir gezgin ve bir gündüzdüşü figürü olarak betimlenebilecek flanörü, Baudelaire'in yapitları üzerinden tarif eden Firat Mollaer'e (2015) göre sözcük, “kapitalist modernleşmenin ürettiği modernlik durumunda çalışan flanörün bir modernist tip olarak modernleşmeye verdiği tepkinin bir örneği gibi okunabilir" şeklinde bir açıklamaya imkân tanımaktadır.

Leos Carax'ın dâhil olduğu Batı toplumunun zihniyet yapısına dair eleştirilerini somutlaştırmak için, bir Mutlak Öteki olarak Mösyö Merde'yi yarattı̆̆ı ve ona başvurduğunu söylenebilir. Kendisini ifade etmek için ötekiye ihtiyaç duyan, benlik inşası uğruna öteki olarak kodladıklarını ötekileştiren ve sonrasında ötekileştirdikleri ile duygudaşlık geliştirme ve özdeşleşme hedefleyen, bir özne olarak Batının açmazları Merde ile gözler önüne serilmektedir. Batı dışında bir zihniyet yapısına sahip olmakla beraber, Batının kendisine yönelik şiddetine rağmen onu bağışladığı gibi bir de kimi unsurlarını benimseyen Japonya'nın söz konusu hoşgörüsünün sınırlarını bir Mutlak Öteki ile ölçerek işe başlayan Carax, sonrasında modernitenin başkenti olarak da anılan Paris'te, öteki ihtiyacının karşılanması için şimdilik yeterli olan Mutlak Ötekinin bile yakın gelecekte güzel olarak bulunup sıradanlaştırılabileceğine işaret etmektedir. Carax filmografisinde, sinematografik bir flanör işlevini gören Merde'nin grotesk dişsallığ1 ve kötücül eylemlerinin, politik doğruculuğun riyakârlığını açık edecek şekilde, uygarlık kıstaslarına ve çağdaş normlara baskı uygulayarak, sınırlarını zorlama amacı taşıyabileceğini söylemek mümkündür.

\section{Sonuç}

Soğuk Savaş'ın ardından ekonomi politiğinde, serbest piyasa kapitalizminin küreselleşme gayesinin yanında, sosyal bilimlerin omurgasını oluşturma noktasında da Batı zihniyeti nüfuz alanını genişletmiştir. Kültür ve kimlik kavramlarına yönelik ve söz konusu kavramlardan yola çıkılarak ortaya konulan çalışmalarla şekillenen bu alanda, öteki 
sözcüğün öne çıtığı görülmektedir. Adeta yayılmacı bir çehre ile hemen her başlıkta karşılaşılmaya başlanan ötekinin, bir kavram halini alışı, onu daha da dikkate değer bir noktaya taşımıştır. Batılı bir bakış açısı üzerinden kodlanan öteki algısının, küresel bir ötekiye, ötekileştirmeye ve ötekileştirme karşıtlığına yönelik bir yayılışı söz konusu olmuştur. Özne ve nesnenin konumlandırılması ve benlik inşası amacıyla, süreç içerisinde giderek, mecburi bir gereksinim halini aldığ 1 iddiasıyla meşruiyet kazanan öteki kavramına yönelik ikaz ve itirazların, bakış açısının tektipleşmesine yönelik bir tepki olduğunu söylenebilir. Tartışmaya perspektif uzamdan katkı sağlayan Ulus Baker (2015: 52-53), öznenin kurgulanabilmesi için gereken bakış açısının özne yerine nesnelerde var olduğunu ve özneleşebilmenin yolunun ancak ve ancak nesnelerin bakış açllarında yer edinmekten geçtiğini dile getirmektedir. Bu yaklaşımda nesne olarak adlandırılan toplamı öteki olarak yorumlamak ve ötekinin bakış açısında yer etmeden benlik inşası ile özne tahakkümünün gerçekleşemeyeceğini söylemek mümkündür.

Öteki ve ötekileştirmeyi Batı zihniyete içkin olarak gören Baudrillard, ötekiye yönelik ilgi artışının ötekinin imkânsızlığına doğru yol aldığını belirterek kökten öteki adlandırmasını yapmaktadır. Baudrillard'a (2012: 116) göre artık yabancılaştırıcı, bakış açısı sağlayıcı, ayna işlevi görerek yansıtıcı ve bu sayede özne ile kendilik perspektifi sağlayıcı öteki kalmamıştır; özne, aynılaşarak katıksız bir yinelenmeye mahkûm edilmiştir ve artık bir öteki cehennemi yerine kendi cehenneminden söz edilmelidir. Kültür ve kimlik temelli, tarih boyunca halkların iletişim ve etkileşimlerinden doğarak yabancılığa, ırkçılığa, saldırganlığa yol açmış, Batı bakış açısıyla ötekilik bağlamında Baudrillard'ın somutluğunu yitiren kökten öteki söylemi, doğru olmakla beraber yeni bir öteki söyleminin tartışılmasını zorunlu kılmaktadır. Zira zaman ve mekân farklılıkları içermekle beraber, geçmişte de günümüzde de, din, ırk, kültür ve kimlik ayırt etmeksizin öteki olarak bellenmiş ve ötekileştirilmiş kümeler mevcuttur. Mutlak Öteki olarak kavramsallaştırılabilecek bu kümelerde akıl hastaları, bedensel deformasyon taşıyanlar, kilolular gibi, özellikle küreselleşme bağlamında büyük yol kat etmiş günümüz dünyasında, hemen her yerde olağan kıstaslar haricinde kalanlar yer almaktadır. Özellikle çirkinlik sözcüğü üzerinden fiziksel olarak, etik ve ahlak bağlamında ise içsel açıdan, dünyanın her yerinde çoğunluğun dişında bırakılanlar Mutlak Ötekileri oluşturmaktadır.

Dışsallıkta grotesk bir görünüme sahip olmanın ve eylemler açısından kötü olarak kodlanmanın beraberinde getirdiği Mutlak Ötekilerin, klasik öteki tartışmalarının giderek daha çok yer aldığı ve ötekileştirme eyleminin aşılması niyetiyle öteki olarak işaret edilenlere daha sik yer verilen sinemada henüz yeterince işlenmediği görülmektedir. Sinema tarihinde Mutlak Ötekiye dair az sayıda örnekle karşılaşılmakla beraber, hem kısa hem uzun metrajda, son yıllarda Mutlak Ötekilerin ele alındığı yapıtlar görülmektedir. Yönetmenliğini yaptığı filmlerin tamamında toplum dışında kalan veya bırakılan uç karakterleri işleyerek, bir anlamda göz ardı edilmiş öteki ve ötekileştirmelere eğilen, Fransız sanatçı Leos Carax'ın iki filminde yer alan Mösyö Merde karakteri ise, Mutlak Ötekiyi tam anlamıla karşılamaktadır.

Görünüm itibarıyla grotesk, eylemleri açısından da apaçı kötülük sağlayan Mösyö 
Merde, ilk olarak, üç orta metrajdan oluşan ve Carax'ın bir bölümünü çektiği 2008 yapımı Tokyo!'da Merde adlı epizotta görülmektedir. 2012 yılında ise Carax'ın yönettiği Kutsal Motorlar' da Mösyö Merde bir kez daha, aynı görünüm ve eylemlerle sahne almaktadır. Bir flanör edasıyla gezgin halini alırken, Tokyo ve Paris kentlerinde doğal, olağan ve sıradan akışa müdahale ederek, işleyişi bozuntuya uğratan Merde, güncel ve uygar toplumun kıstaslarını, iğdiş edilmiş bedeniyle iğdiş edilmiş eylemlere başvurarak adeta iğdiş etmektedir. Leos Carax'ın çağdaşlık başlığı altında hoşgörü, duygudaşlık, özdeşleşme, iyilik, etik ve ahlak gibi kavramları, küreselleşmiş Batı zihniyeti nezdinde eleştirel bir bakış açısına oturttuğu iki filmde, Mutlak Öteki olarak Mösyö Merde, bir araç halini almaktadır.

Bütünlüklü bir zihniyet haliyle, yüzyıllar boyunca öteki olarak belleyip ötekileştirdiği toplamlara yönelik, yıkıcı bir seyir izlemiş uygulamalara imza atmış Batının, ötekileştirmeyi aşmak adına öne çıkarttığı öteki kavramının, giderek ötekiyi kökten ötekiye dönüştürerek ortadan kaldırmaya yaradığı görülmektedir. Bu noktada Mutlak Öteki, öteki olanın aslen kimler olduğuna ve benlik inşası vesilesiyle özneleşmeye yarar olarak değerlendirilen ötekileştirme eyleminin nerede aranması gerektiğine işaret ederek yol gösterici olabileceği düşünülmektedir. Sanat disiplinleri arasında kitlesellik ve evrensellik bağlamında en etkin ve belirleyici olan sinemanın, Mutlak Ötekiyi işler oluşu önem arz etmektedir. Carax'ın yarattı̆̆ı Mösyö Merde karakteri, Mutlak Ötekinin sinemasal sunumlarda açabileceği tartışmalara önayak olmaktadır. Bununla beraber Leos Carax sinemasında Mösyö Merde, sinematografik etik açısından geliştirilebilecek uç noktada duygudaşlık ve özdeşleşme imkânları ile benlik, ötekilik, özne, nesne kavramlarında ön kabulden muaf tutulamayan yaklaşımlar açısından yeni ufuklar sağlamaktadır. Sinemada Mutlak Ötekiye dair işleyişlerin çok daha zengin bir felsefi zemine imkân tanıyacağ aşikârdır.

\section{Kaynakça}

Baudrillard, J. (2012). Kötülüğün Şeffaflığı (5. Baskı). Işık Ergüden (Çev.). İstanbul: Ayrinti.

Baker, F. (Yapımcı), \& Lynch, D. (Yönetmen). (1977). Eraserhead [Sinema Filmi]. ABD: Libra.

Baker, U. (2015). 24 Şubat 1998 Tarihli Ders. Tansu Açık (Ed.). Sanat ve Arzu içinde (s. 35-68). İstanbul: İletişim.

Bataille, G. (2016). Edebiyat ve Kötülük. (4. Baskı). Ayşegül Sönmezay (Çev.). İstanbul: Ayrinti.

Bilgin, N. (2007). Kimlik İnşası. Ankara: Aşina.

Berger, A. (Yapımc1), \& Field, T. (Yönetmen). (2006). Little Children [Sinema Filmi]. ABD: New Line.

Biles, J. (2013). Holy Motors, Journal of Religion \& Film, 17 (1), 1-8.

Bisgaard, N. (Yapımc1), \& Abbasi, A. (Yönetmen). (2018). Gräns [Sinema Filmi]. İsveç: Meta Film.

Brenner, R. (Yapımc1), \& Vallée, J. M. (Yönetmen). (2013). Dallas Buyers Club [Sinema 
Filmi]. ABD: Truth.

Cooper, M. C. (Yapımc1), \& Ford, J. (Yönetmen). (1956). The Searchers [Sinema Filmi]. ABD: C. V. Whitney.

Dahan, A. (Yapımcı), \& Carax, L. (Yönetmen). (1986). Mauvais Sang [Sinema Filmi]. Fransa: Plain Chant.

Denessen, M. G. (Yapımc1), \& Trier, L. V. (Yönetmen). (2013). Nymphomaniac: Vol. II [Sinema Filmi]. Danimarka: Zentropa.

Eagleton, T. (2006). Kuramdan Sonra (2. Baskı). Uygar Abacı (Çev.). İstanbul: Literatür.

Esper, D. (Yapımc1), \& Browning, T. (Yönetmen). (1932). Freaks [Sinema Filmi]. ABD: Metro Goldwyn Mayer.

Fechner, C. (Yapımc1), \& Carax, L. (Yönetmen). (1991). Les Amants Du Pont-Neuf [Sinema Filmi]. Fransa: Gaumont.

Gardner, D. (Yapımc1), \& Jenkins, B. (Yönetmen). (2016). Moonlight [Sinema Filmi]. ABD: A24

Hidalgo, C. (Yapımc1), \& Lee, S. (Yönetmen). (2017). The Things You Think I'm Thinking [Kısa Film]. Kanada: Meraki.

Ibanes, J. (Yapımc1), \& Stone, O. (Yönetmen). (2012). The Untold History of the United States Chapter 3: The Bomb [Belgesel Film]. ABD: Showtime.

Ilgaz, A. (2001). Amerikan Sinemasında Basmakalıp Tipleme. (Yayımlanmamış yüksek lisans tezi). Marmara Üniversitesi/Sosyal Bilimler Enstitüsü, İstanbul.

Kearney, R. (2012). Yabancılar, Tanrılar ve Canavarlar: Ötekiliği Yorumlamak. Barış Özkul (Çev.). İstanbul: Metis.

Marignac, M. (Yapımc1), \& Carax, L. (Yönetmen). (2012). Holy Motors [Sinema Filmi]. Fransa: Pierre Grise.

Mollaer, F. (2015). Baudelaire' in Modernlik Kehanetleri: Modernleşmeye Karşı Estetik Modernizm. https://www.e-skop.com/skopbulten/baudelairein-modernlik-kehanetlerimodernlesmeye-karsi-estetik-modernizm/2310 adresinden elde edildi. Erişim Tarihi: 30.12.2019

Moraz, P. (Yapımc1), \& Carax, L. (Yönetmen). (1984). Boy Meets Girl [Sinema Filmi]. Fransa: Abilene.

Nietzsche, F. (2019). İyiliğin ve Kötülüğün Ötesinde. (5. Baskı). Mustafa Tüzel (Çev.). İstanbul: İş Bankası.

O'Connor, F. (2019). Ucubeler ve İnsanlar: Edebiyatta Grotesk ve Gerçeklik. Elçin Gen (Çev.). https://www.e-skop.com/skopbulten/ucubeler-ve-insanlar-edebiyatta-grotesk-vegerceklik/4305 adresinden elde edildi. Erişim Tarihi: 30.12.2019

Onrust, F. (Yapımc1), \& Molter, J. (Yönetmen). (2018). Kind [Kısa Film]. Hollanda: Family Affair.

Öğdül, R. (2013). Gezi Direnişi'nin Grotesk İmgesi. http:/ / rahmiogdulbirgun.blogspot.com/2013/07/gezi-direnisinin-grotesk-imgesi.html adresinden elde edildi. Erişim Tarihi: 30.12.2019

Pause, J. (2014). Cinema's Journey into Homelessness Leos Carax's Holy Motors, 
Berghahn Books and Journals, 4 (1), 133-136.

Sanger, J. (Yapımc1), \& Lynch, D. (Yönetmen). (1980). The Elephant Man [Sinema Filmi]. ABD: Brooks.

Sawada, M. (Yapımcı), \& Carax, L. \& Gondry, M. \& Joon Ho, B. (Yönetmen). (2008). Tokyo! [Sinema Filmi]. Japonya: Kansai.

Tanaka, T. (Yapımc1), \& Honda, I. (Yönetmen). (1954). Gojira [Sinema Filmi]. Japonya: Toho.

Uluç, G. (2009). Medya ve Oryantalizm. İstanbul: Anahtar.

Üzümkesici, B. (2018). Toplumsal Bedenden Çıkan Tekinsiz Sesler: Gezi'nin Estetiği ya da T1k...tık...tık... http://www.e-skop.com/print.aspx?PageID=3803 adresinden elde edildi

Wilson, J. (Yapımcı), \& Costner, K. (Yönetmen). (1990). Dances With Wolves [Sinema Filmi]. ABD: Tig.

Yürür, F. (2016). Çağdaş Sinemada Auteur: Leos Carax. Berk Çaycı, Ayşegül Elif Karagülle, Sena Aydın (Ed.). İstanbul Ticaret Üniversitesi 2. Lisansüstü Öğrenci Kongresi Bildiriler Kitabı içinde (s. 95-113). İstanbul: İstanbul Ticaret Üniversitesi

Žižek, S. (2006). Kırılgan Temas. (2. Baskı). Tuncay Birkan (Çev.). İstanbul: Metis

Wilson, J. (Yapımc1), \& Costner, K. (Yönetmen). (1990). Dances With Wolves [Sinema Filmi]. ABD: Tig.

(2018). Border Cast and Crew Q\&A | Toronto Uluslararası Film Festivali.

https://www.youtube.com/watch?v=d-cF B58Ui4\&feature=emb title adresinden elde edildi. Erişim

Tarihi: 30.12 .2019 